homology. It is utterly unphilosphocal to accept without the clearest proof such a structural modification as this change in position of the mandibles would require, and the modification of the ordinary labium into a beak of this character is a process that ought to be proven. It seems to be assumed that the "labium" of the hemiptera is the same as the "labium" of the diptera, e. g. Culex, and if this is so, I have a paper now in press, in which I claim to prove that this "labium" in the diptera is really only a modified galea, or a maxillary structure. I hope to prove some time in the future, when I can get the necessary material, how this modification of the hemipterous mouth came about, and that the mandibles do not, habitually, become internal mouth structures so long as there are other organs enough more naturally situated.

\section{Explanation to Base figures.}

Fig. r. Siphonophora avenae. a, beak; $b$, bristles of mouth-"mandibles" and "maxillae;" $c$, antenna of winged viviparous female.

Fig. 2. Aphis brassicae. a, antenna of wingless forms; $b$, antenna of winged viviparous female; $c$, beak of young lice; $d$, beak of mature, winged form.

Fig. 3. Aphis cucumeris. a, antenna of winged viviparous female; $b$, beak of wingless forms.

Fig. 4. Myzus cerasi. $a, 3^{\text {rd } ; ~ b . ~} 5^{\text {th }}$; $c, 6$ th joint of antenna of winged viviparous female.

Fig. 5. Aphis persicae-niger. a, antenna of immature forms, joints 5 and $6 ; b, 3^{\text {rd; }}$ $c, 4^{\text {th }} ; d, 5^{\text {th }} ; e, 6$ th joint of antenna of winged viviparous female; $f$, sensory pit from front; $g$, same from side.

\title{
NOTES ON TWO SPECIES OF DATANA WITH DESCRIPTIONS OF THEIR LARVAL STAGES.
}

\author{
BY HARRISON G. DYAR, RHINEBECK, N. Y.
}

Of all the closely related species of this genus, the two which approach each other the most nearly and are most difficult to distinguish in the imago state, are $D$. major and $D$. drexelii. I have elsewhere called attention to the main feature by which they are to be distinguished, which, after all, is only a matter of degree of coloration. The species differ, or rather tend to differ, in other points beside the brightness of the costal shade, namely, in the more entire outer margin of the primaries, and the darker more even coloration of the wings of $D$. major.

The size is the same in both species, there are no markedly distinctive male genital characters, and the lines and 
spots are arranged in the same manner; in fact, there is no absolutely constant difference, either in structure, markings or coloration, between the two so far as I have been able to observe, and I have no doubt that specimens may occasionally occur which it would not be possible to refer positively to one species or the other by an examination of the imago alone. It would at first seem that these species must be more closely related than others in the genus, perhaps hardly yet distinct; but when we consider the larval stages, it is at once apparent that they are widely separated, more widely, in fact, than many other species of Data$n a$ which are readily separable in the imago state. This difference would seem to indicate rather a long inherited similarity between the moths than very recent derivation from a common ancestor. While the moths, it may be, have remained constant to their former type, or undergone a similar development, the larvae have diverged greatly, which would seem to correspond to the general rule in lepidoptera, that the larvae are often the first to vary. The eggs of $D$. major and $D$. drexelii differ markedly: the larval differences appear in the first stage and are kept up and intensified throughout the larval period, and only when the pupa stage is reached, does the close resemblance observed in the moths begin. The cause of the divergence in the larvae,especially at maturity, is not very obvious, particularly in the peculiar ornamentation of $D$. major, which differs from that of all of the other Datana larvae so far known.

$D$. drexelii is abnormal only in the predominance of yellow about the prothoracic and the 8th, $9^{\text {th }}$ and Ioth abdominal segments, ${ }^{*}$ and this might serve as an excellent protection, in that the bunches of yellow striped larvae with their extremities elevated in their customary position, resemble the little clusters of flowers of the Witch-Hazel with their linear yellow petals, which begin to blossom in September, just as the larvae become conspicuous. What protection, if any, their coloration affords on the Deerberry, their other food-plant, I am unable to say, as they occur almost exclusively on the Witch-Hazel in this vicinity. (Rhinebeck, N. Y.)

But as to D. major its curious spots do not resemble anything so far as I can see. It is to be noted, however, that the habits of the two species differ, for while $D$. drexelii are always gregarious, $D$. major, when they do not separate entirely, feed farther apart, and tend to scatter more in the last stage than almost any other species, and the change in ornamentation from lines to spots, which they undergo in the last molt, may be of use to them with their changed habits.

\section{Datana major, $G . \mathscr{R} R$.}

$E g g$. Sub-pyriform, of less diameter and cylindrical for a short distance at the top, recalling the structure of D. palmii; flattened at base or a little hollowed; evenly flat on top with a sharp angle hetween top and sides. Color uniform sublustrous white, a rather

* In this article, I have followed the nomenclature used by Dr. Packard for the larval segments, as it is not possible to describe intelligently the markings of Datana by the usual method. 
Spiracles velvety black. Hair white, rather long, beside numerous fine, short black hairs, all growing from minute black tubercles. Length of larva at maturity $60 \mathrm{~mm}$. The form of this larva with canary yellow bands and spots did not occur in any of the examples from which these notes were made (a brood of 55 and another large brood observed in the field). I have formerly found a few yellow ones among a brood of white spotted $D$. major, and occasionally a brood entirely yellow. Though the difference in coloration is very marked between the two forms, it is evidently, from its mode of occurrence, only a variation. A similar variation occurs in D. palmii* and less markedly in $D$. contracta.

Pupa. Formed in a subterraneous cell. In shape it is robust, cylindrical, thickest centrally, and rounded to the head; cases distinct; a slight creased elevation between the eyes. Abdominal segments slightly tapering; cremasters, two, very short, not well separated, each with three spines, the posterior one the longest, but often two, or partly aborted. Cases creased, body coarsely punctured, very finely in the movable sutures. Color dark or blackish mahogany. Length 25 mm., width $9 \mathrm{~mm}$. This stage lasts through the winter and the species is single brooded. The duration of the larval stages was as follows: - Ist stage, not observed, but probably about five

* I would like to call attention to the relationship that evidently exists between $D$. palmii and $D$. major. They are alike in egg structure, in the feature of bico. lorous larval hairs (which does not occur in any other species to my knowledge), in coloration of head and lines and in the slightly scalloped forewings of the moth. days; 2 nd stage, 6 days; 3 rd stage, 8 days; $4^{\text {th }}$ stage, 9 days.

Food-plant : Andromeda ligustrina.

Larvæ from Ulster Co., N. Y.

Datana drexelil, $H y . E d w$.

$E g g$. On the type of D. ministra. Subcylindrical, of a little greater diameter near the bottom than near the top; vertex rounded; base nearly flat. Color shiny whitish, the circular lid-like top very white and shiny, with a central small round black spot. Diameter .7 $\mathrm{mm}$. In hatching, the larva eats away the lid, and emerges from the hole thus formed.

First stage. Head rounded, black, shiny; width $.5 \mathrm{~mm}$. When newly hatched, the larva is scarcely distinguishable from $D$. major. The anal feet are rather long and elevated. Body sordid yellow, cervical shield, anal plate and feet, blackish. A number of short hairs from the head and from about six rows of small blackish tubercles which are larger in proportion than in the subsequent stages. As the stage advances, the body becomes reddish with four lateral stripes on each side and three ventral, about as wide as the intervening spaces, dull yellow and confluent posteriorly. During this stage, the larvae eat the parenchyma in the same manner as $D$. major. I have estimated that a single larva eats about $90 \mathrm{sq} . \mathrm{mm}$. of Witch-Hazel leaf.

Second stage. Head black and shiny with a few hairs, width I. I mm. Body brown, stripes dull yellow, narrower than the intervening spaces, extending 
from the cervical shield and the anterior edge of the prothoracic segment to the anal plate and becoming a little confluent there. Cervical shield, anal plate, thoracic and anal feet and the abdominal feet outwardly black. Hair short and pale. During this stage, the larvae eat the whole leaf.

Third stage. Head higher than wide, depressed at the sutures of the clypeus; smooth shiny black, width r. $8 \mathrm{~mm}$. Body brown, the stripes yellow, confluent posteriorly and along the anterior edge of the prothoracic segment. Otherwise as in the previous stage.

Fourth stage. Head shaped as before, smooth; centrally depressed at the top of the clypeus and more slightly along the central suture; clypeus and labrum wrinkled; all shining black; width $3.2 \mathrm{~mm}$. Cervical shield black or partly brown, in some examples nearly all light brown; anal plate, thoracic feet and the abdominal feet outwardly, black. Body black or partly brown, the anterior half of the prothoracic segment yellow, the stripes strongly confluent on the last segment. The bases of the legs and corresponding spots on the legless segments, as in the inature larva, of a darker yellow than the lines. Each segment is shaded centrally with this yellow, but it does not cause the lines to appear confluent on account of its darker shade. Hair sordid white beside other short fine brownish hair seen with a lens.

Fifth stage. Head as high as wide, flattened in front, depressed at the upper part of the sutures of the clypeus, punc- tured. Clypeus and labrum somewhat wrinkled. Color shiny black, the antennie and palpi white-ringed, their bases greenish. Width $5.4 \mathrm{~mm}$. Body black, cervical shield honey yellow, anal plate, thoracic and anal feet and the abdominal feet outwardly, black. Anterior half of the prothoracic segment yellow; stripes narrower than the spaces, citron yellow, running iato the yellow part of the prothoracic segment and confluent posteriorly on the tenth abdominal, which is all yellow except the anal plate and a dorsal band. The three upper lateril lines are connected also on the eighth and ninth abdominal segments by a broad dark yellow shade. The bases of the legs and corresponding spots on the apodous segments (on the first, second, and seventh, eighth and ninth abdominal segments) also dark yellow, forming expansions of the subventral line and reaching the lowest lateral line, except on the thoracic segments and the ninth abdominal. On the apodous segments in the centre of each yellow patch, is a small black spot, representing the absent legs, but this is not present in all examples. IIair rather abundant, sordid white, the long and short hairs concolorous, arising from minute blackish tubercles which, in the black parts of the body, are each surrounded by a minute yellow ring.

Pupa. Exactly like that of D. major; the two cremasters each bear three spines in a transverse row, the posterior one the longest. Length $28 \mathrm{~mm}$; width 10 $\mathrm{mm}$.

Single brooded, the winter being passed in the pupa state beneath the 
ground. The duration of the larval days. stages was as follows.- Ist stage, 5 Food-plan's : Hamamelis vir-

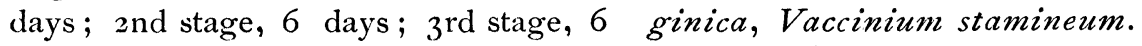
days, $4^{\text {th }}$ stage, 7 days; $5^{\text {th }}$ stage, 7 Larvae from Ulster Co., N. Y.

\section{THE NUMBER OF MOLTS OF LEPIDOPTEROUS LARVAE.}

\section{BY HARRISON G. DYAR, RHINEBECK, N. Y.}

Two articles have already appeared in Psyche on this subject* and it is evident from a perusal of them that considerable confusion exists as to the number of molts of certain species. In this article I propose to establish a criterion by which different observations may be compared and errors detected, for it is no difficult thing to overlook a molt or even to think one has occurred when it has not.

It will be seen by an examination of the following figures that the widths of the head of a larva in its successive stages follow a regular geometrical progression, and if, in examining the measurements of heads taken in following out a life history, any deviation from the calculated progression is shown, it is evidence that an error has been committed or that the larva has behaved in an abnormal manner; but the latter case can readily be distinguished from the former if a moderate degree of care has been exercised in taking the measurements. Hence, if two sets of observations show a different number of stages for the same insect but each

* W. H. Edwards, Psyche, v. 3, p. 159.

A. K. Dimmock, Psyche, v. 5, p. 28. follows its own progression, we may conclude that this variation is actual; but if either set shows a lack of regular progression that one we must regard with suspicion. Corroborative observations of the kind indicated are to be desired and until we have them we can not speak with confidence about the number of molts of any species. I recommend that all who hereafter describe larval stages give the width of the head for each stage. I have selected the head as the part not subject to growth during the stage, and its width as the most convenient measurement to take.

In the following I give first the calculated widths of head under each species, with the ratio, followed by those that were actually found. All measurements are in millimeters and may be considered accurate to within . I mm. Certain irregularities are commented upon in the notes to which the small numbers refer.

FOUR STAGES.

Callosamia promethea Drury. calc. r.I r.6 $2.33 .3, \mathrm{r} .7 \mathrm{O}$ found 1.0 I.7 $2.33 .3^{1}$ 

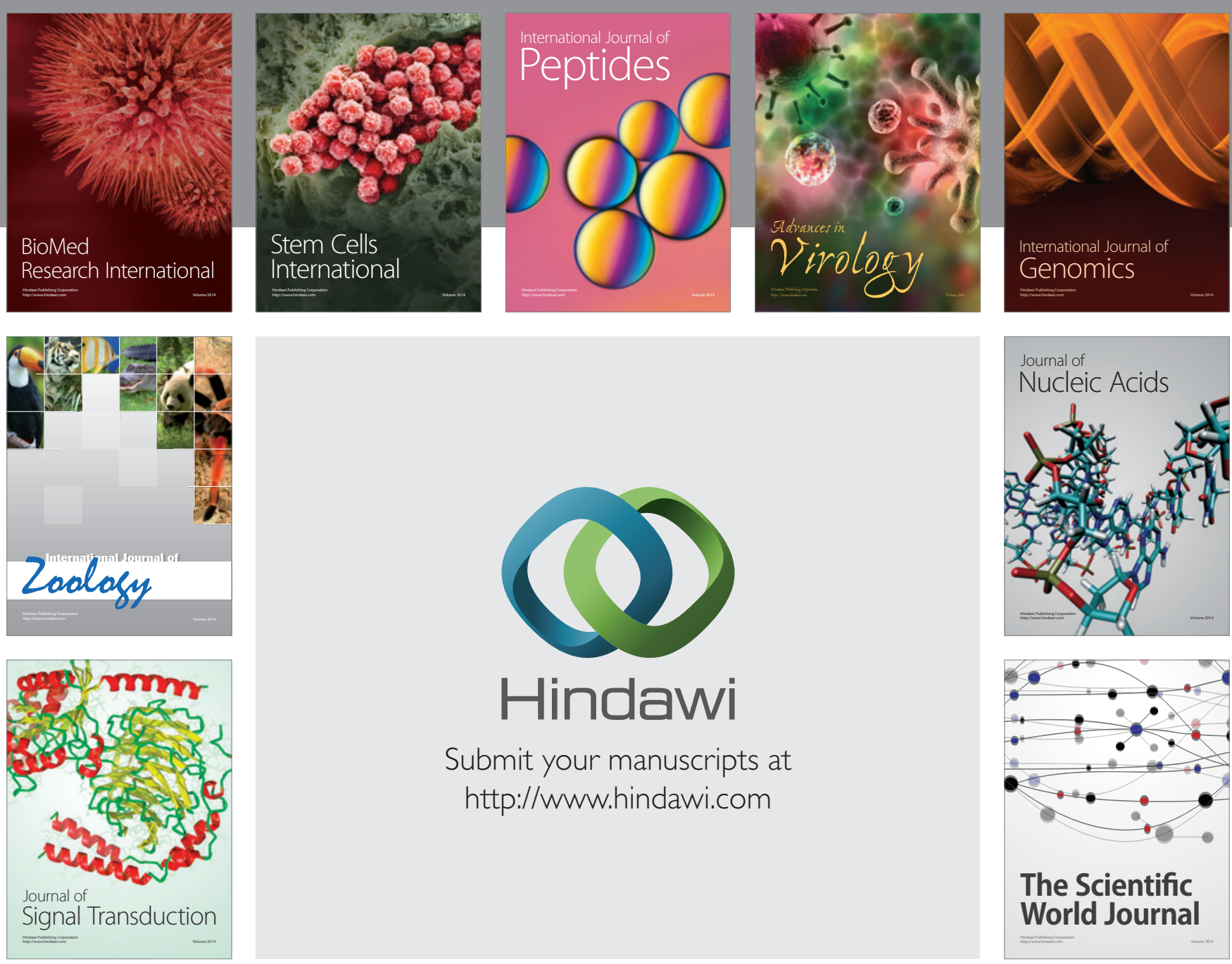

Submit your manuscripts at

http://www.hindawi.com
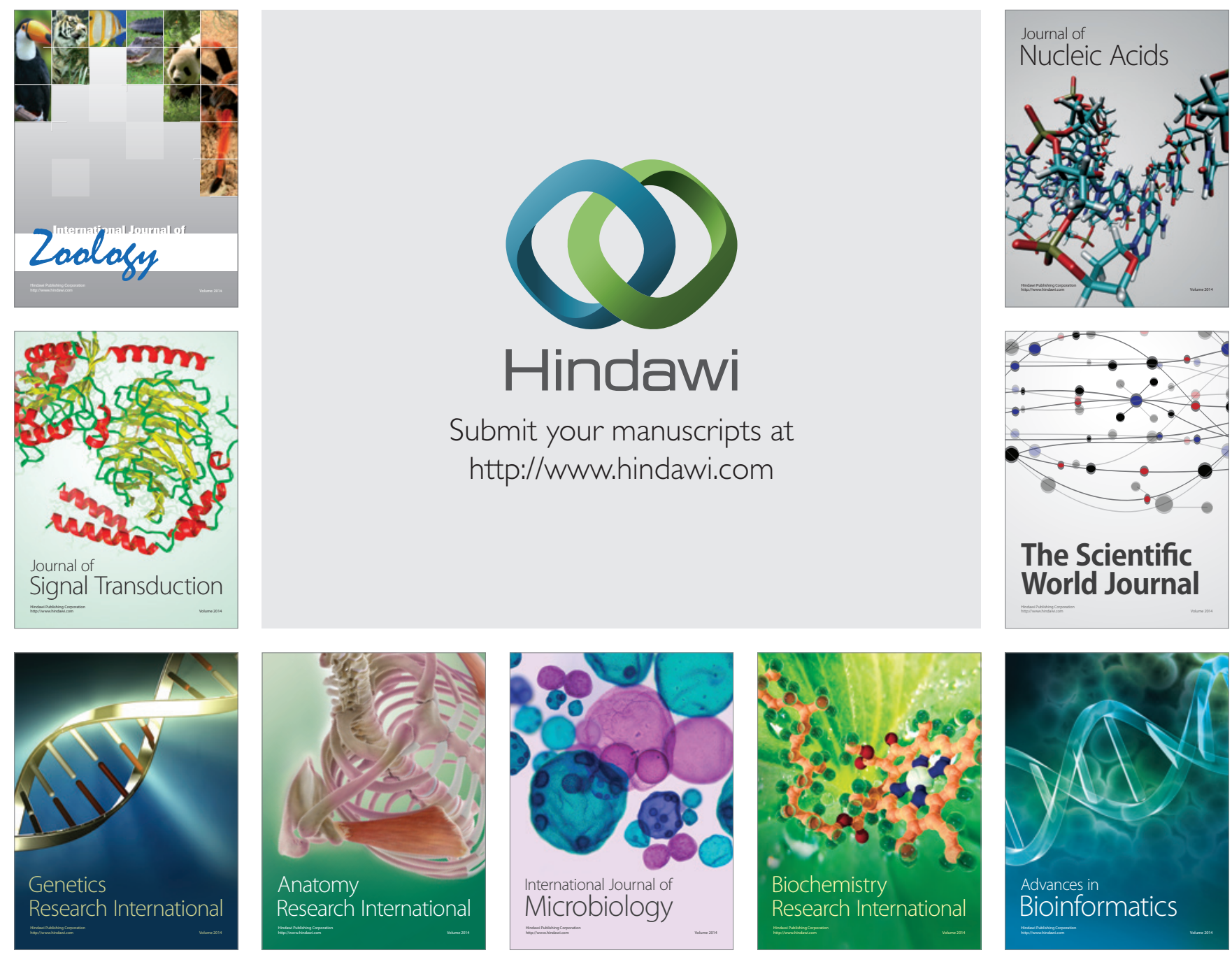

The Scientific World Journal
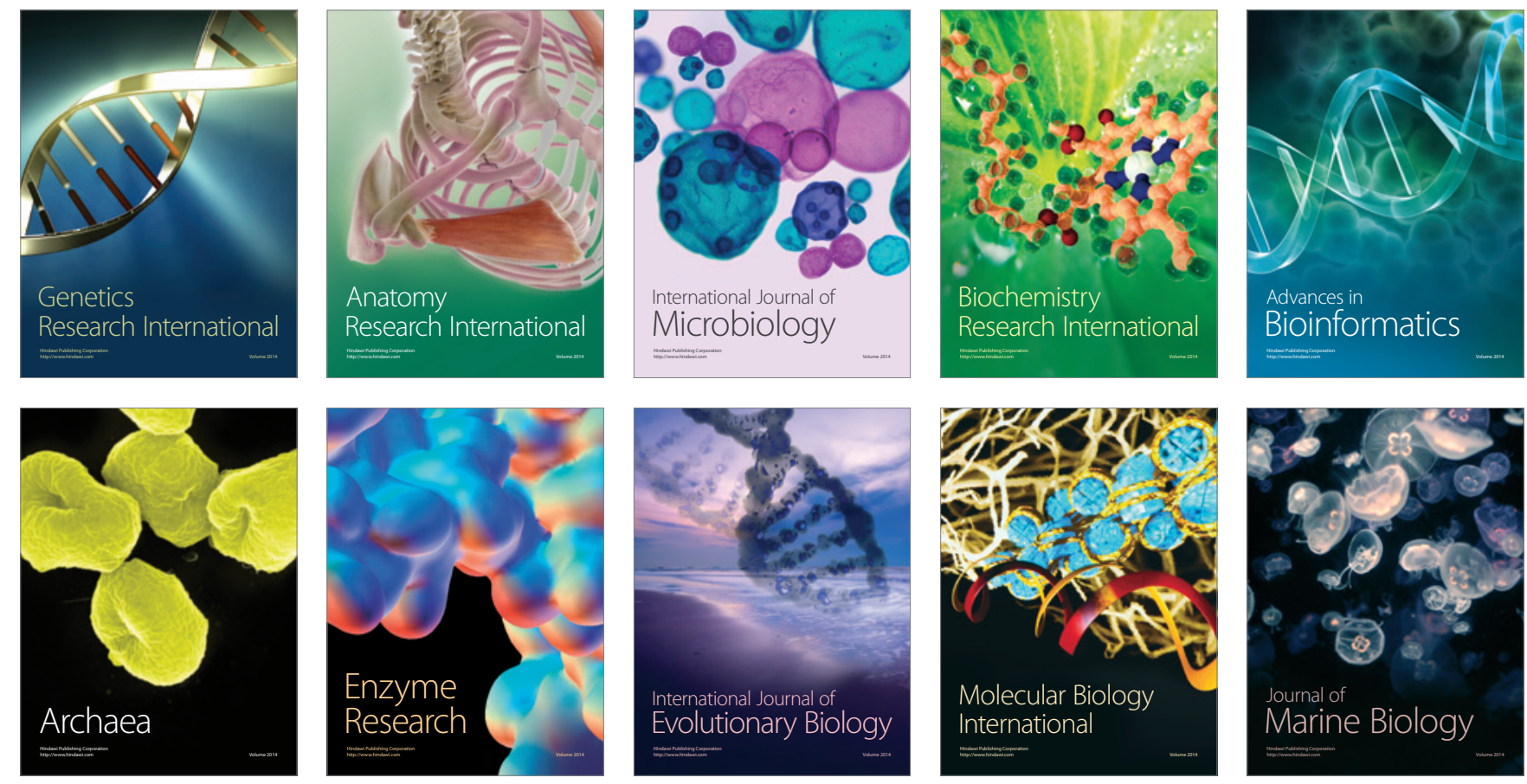